\title{
The Implementation of Mathematics Learning in the Preparation Center Islamic Kindergarten Raudhatul Jannah City of Payakumbuh
}

\author{
Misrayeti ${ }^{1}$ and Nenny Mahyuddin ${ }^{2}$ \\ ${ }^{1}$ Early Childhood Education Department, Padang State University, Padang, Indonesia, Misrayeti47@gmail.com \\ ${ }^{2}$ Early Childhood Education Department, Padang State University, Padang, Indonesia, \\ nenny.mahyuddinpaud@gmail.com
}

\begin{abstract}
This study aims to describe the implementation of learning the development of science at the center of science and natural materials of the Islamic Kindergarten Raudhatul Jannah, Payakumbuh City. Science is part of the scope of cognitive development that must be developed in kindergarten. Stimulating the development of science will enable children to process new information through concrete experiences, explore, classify, stimulate curiosity, find things, explain, elaborate, and evaluate, so children can learn about the world around them. The implementation of learning activities in science and natural materials starts from the planning, implementation and evaluation of learning. In planning, it looks material and activities that will be taught to children, then the media and learning tools as well as the arrangement of the playing environment that children will play. During the implementation, it was seen the learning process of the development of science in the center of science and natural materials as a whole. Finally, evaluation in the form of assessment is seen during the activity process and documentation of assessment results. The research method used is descriptive qualitative research, in which the researcher will describe in full the research results. This research was conducted at the Islamic Kindergarten Raudhatul Jannah City Payakumbuh City in 2019. Data collection techniques through observation, interviews and documentation carried out in the field in detail and clearly in order to get a picture related to the implementation of learning science development in science centers and natural materials Raudhatul Jannah Islamic Kindergarten. Based on the data analysis, the results of the study indicate that the planning, learning implementation and evaluation of learning outcomes have proceeded according to procedures and are well documented. It was concluded that learning in science and natural materials could develop children's scientific abilities in the Islamic kindergarten Raudhatul Jannah. The results of this study are also useful as insights and further research development studies to develop other children's intelligence.
\end{abstract}

\section{Keywords: Science Development, Science Center and Natural Materials}

\section{INTRODUCTION}

One form of early childhood education units in the formal education pathway is a kindergarten (kindergarten) which aims to help students develop a variety of potential both psychic and physical including religious and moral values, physical motor, cognitive, language, social emotional and arts to ready to enter primary education. As the name suggests kindergarten is expected to be a pleasant place for children aged 4 to 6 years. It is unfortunate that a kindergarten that is supposed to be a fun place actually becomes a boring place, there is no happiness and even makes children depressed with the learning process given by the teacher.

The learning process in kindergarten should take place in a pleasant atmosphere, involving all five sensory functions, and can satisfy a child's curiosity. So that the process can be achieved, various human resources are needed in the form of professional and creative teachers. Professional and creative teachers are expected to be able to develop ideas and skills in teaching and in developing learning activities.

At the Raudhatul Jannah Islamic Kindergarten the child's learning process is highly considered. With classroom management using a learning center model can take place in a pleasant atmosphere, involving all five sensory functions, and can satisfy a child's curiosity. This condition makes Raudhatul Jannah Islamic Kindergarten become one of the most popular institutions in the City of Payakumbuh and the surrounding District of Lima Puluh.

Raudhatul Jannah Islamic Kindergarten was established in 1990. The current number of students in the 2019-2020 school year is 205 with a group of 3 group A's and 10 group 
B's. The number of teachers is 23 people with 13 class teacher details, 7 center teachers and 1 music teacher. 1 head of kindergarten and 1 deputy head of curriculum. 1 class teacher is responsible for 14 to 15 children. The center teacher specifically teaches the center's activities accompanied by the class teacher and is responsible for all children specifically for learning in their respective centers. The centers in the Islamic Kindergarten Raudhatul Jannah are as follows: 1) centers of science and natural materials, 2) centers of preparation, 3) centers of role playing, 4) centers of blocks, 5) centers of art and creativity, 6) centers of music and sports, 7) multimedia and library centers, 8) worship centers.

The learning model with the center approach is one of the advantages of Raudhatul Jannah Islamic Kindergarten. The advantage compared to other kindergartens also applies the center model is that there are center teachers who do not concurrently as class teachers so that the center teachers focus on learning the center for which they are responsible. One of the centers that researchers want to observe is science and natural materials. At this Center the researcher wants to see the learning of science development carried out, starting from how the learning planning is designed, what kind of learning implementation is carried out and how the process and form of learning evaluation is carried out.

\section{A. The Nature of Early Childhood Development}

Early childhood is an individual who is undergoing a process of growth and development rapidly and fundamentally for the next life. Child development has begun since the child in the womb both brain development and motor physical development. In addition to the physical and motorized growth and development of moral development (including personality, character, and character), social, emotional, intellectual, and language also take place very rapidly.

Early childhood is at a different stage of growth and development from adults, therefore it is very much needed learning in accordance with the level of growth and development. Sujiono (2009: 7), suggests the characteristics of early childhood, namely: a) the child is egocentric: children tend to see and understand things from their own point of view and interests, b) children have a great curiosity: their curiosity is very varied, depending on what attracts his attention, c) children are social creatures: they like to work together in making plans and completing their work, d) children are unique: children are unique individuals, each of which has an innate, interests, capabilities and background different lives from each other, e) children are generally rich in fantasy: This is because the child's imagination develops beyond what he sees, f) the child has a short concentration power: the child always quickly turns his attention to other activities, unless the activity is aside from being fun also varied and not boring, g) children are the most potential learning periods, because of the age of the child early is the golden age.

From the expert opinion above it can be concluded that the characteristics of Early Childhood are unique individuals, where each child has interests, talents and innate, as well as different capabilities and backgrounds of life.
Early age children have a great curiosity; each child is different from one another. The concentration power of children in an activity is very short, unless the activity can make a child happy. Early childhood has a critical point that needs attention that is different from later childhood. The critical point is explained by Kartadinata (in Aisha, 2007: 3), namely: a) Requires a sense of security, rest and good food, b) coming into the world that is programmed to imitate, c) Requires practice and routine, d) has a need for ask lots of questions and get answers, e) the way of thinking of children is different from adults, $\mathrm{f}$ ) requires direct experience, $\mathrm{g}$ ) play is the world of ankle-age.

Based on the above opinion it is clear that early childhood not only has characteristics but has a critical point that needs to be considered at each stage of its development. Giving the right stimulation will help the child's development to the maximum. Appropriate stimulation can be in the form of activities given to children by taking into account the characteristics and critical points of the child's development.

\section{B. Early Childhood Cognitive Development}

Piaget holds that cognitive development is a genetic process, a process that is based on the biological mechanism of the development of the nervous system. As a person ages, the more complex the composition of nerve cells and the ability to increase. When individuals develop towards maturity, they will experience biological adaptations to their environment that will cause qualitative changes in their cognitive structure.

Associated with early childhood cognitive development are at the sensorimotor stage (0-2 years) and pre-operational (2-7 years). At the sensorimotor stage, children can think through sensing and their perception of various tangible objects, while in the pre-operational stage the child can think by sensing and perceiving not only on real objects but also symbolically. This means that at the pre-operational stage the child can already describe the various things that exist in his mind without these objects.

There are nine characteristics of cognitive development according to Mudjito, 2007: 1) can understand the concept of opposite meanings such as full empty, light-weight of an object, 2) can match geometric shapes (circles, squares and triangles) with real objects or through visualization of images, 3 ) can stack blocks or rings according to their size in sequence, 4) can classify objects that have the same color, shape, and size, 5) can mention pairs of objects, able to understand cause and effect, 6) can arrange daily activities and show when each activity is carried out, 7) recounts 3 main ideas of a story, 8) recognizes and reads writing through images that are often seen at home or at school, 9) recognizes and mentions numbers 1-10.

Based on expert opinion above learning activities that are in accordance with the characteristics of children's cognitive development can be well designed and of course learning outcomes are increasing.

Some aspects of the child's cognitive process include perceptions, memories, thoughts, symbols, reasoning, and problem solving. In connection with this according to Piaget (in Susanto, 2011: 48) the importance of teachers developing cognitive in children is: 1) so that children are able to 
develop their perceptions based on what is seen, heard and felt, so that children will have a complete and comprehensive understanding, 2 ) so that children are able to train their memories of all events and events that have ever happened to them, 3) so that children are able to develop their thoughts in order to connect one event with another event, 4) so that children are able to understand the symbols that are spread in the surrounding world, 5) so that children are able to reason, both naturally (spontaneous), and through scientific processes (experiments), 6) so that children are able to solve the life problems they face, so that eventually children will become individuals who can help themselves. Through cognitive development, thought functions can be used quickly and precisely to overcome a situation to solve a problem.

According to Piaget (in Khadijah: 2016) there are four basic abilities that need to be stimulated in pre-school children, namely: 1) transformation ability: i.e. changes in shape can be introduced to pre-school children through simple experiments, for example blowing a balloon, pouring water into a different glass, change soft objects into various forms, and others. 2) reversibility ability; namely alternative ways of thinking or going back and forth, for example with a picture the child is invited to find a way out of a path that has many twists and turns, or the child is asked to sort numbers from small to larger and then return from large numbers to smaller ones, 3) classification capabilities; that is, children are invited to do classification based on type, shape, color, size, etc., the ability of this classification is three, namely single, multiple and plural classifications. Single for example only based on one aspect such as color. Double has two aspects, for example color and shape, while plural has many aspects, for example the color, shape and basic material. The important thing from this exercise is the ability to think logically. 4) the ability of asymmetric relationships that is not all classifications are based on similarities, but also on the basis of differences. For example, large, small, long, short, high and low, children can be trained to arrange the blocks in sequence from the big to the small or from the long to the short.

By knowing and understanding basic skills that must be stimulated in kindergarten, teachers are expected to be able to provide activities that are able to stimulate these basic abilities so that children develop optimally.

\section{Early Childhood Science}

According to Morisson (2012: 270) Science is an ideal tool to develop children's minds to ask questions about the natural world, science teaches children to appreciate the diversity of life and their interrelations. Stages of simple science learning for early childhood begins with exploring the closest thing to him, food, drinks, hobbies, all activities about him by playing in accordance with the stages of development.

The development of science for early childhood which is part of the scope of cognitive development that examines how children learn, what is learned and allows children to process new information through concrete experiences, explore, classify, stimulate curiosity, find things, explain, elaborate, and evaluating, so children can learn about the world around them.

Science learning activities in kindergarten are essentially developed in learning activities while playing so that they are fun and interesting for children. Learning is done through observation, investigation and experiments to find out and find answers about what is in the surrounding environment. In general, the development of science in kindergarten aims to enable children to actively seek information about what is around them. Whereas specifically science activities in kindergarten aim to enable children to observe various changes that occur, conduct simple experiments, conduct classifying, comparing, estimating and communicating activities and building creativity and innovation in children.

The purpose of the above scientific activities to be achieved in the implementation of science activities in the Islamic Kindergarten Raudhatul Jannah Payakumbuh City. How the process of implementing science learning is carried out will be a material of research that is expected to be useful for the development of activities of early childhood especially in kindergartens.

\section{Approach Center for Science and Natural Materials}

The center and circle method is one of the methods of early childhood learning that puts forward the concept of play for children. This method was adopted from the Beyond Center and Circle Time (BCCT) method. Developed by the Creative Center for Childhood Research and Training (CCCRT) Florida, USA. The center and circle approach is an approach to early childhood education that focuses on children who in the learning process are centered on the play center and when the child is in a circle by using 4 steps (Scaffolding) to support the development of the child, namely 1) the footing of the playing environment, 2) the footing before playing, 3) footing during play, 4) footing after playing. Foothold is a changing support that is adjusted to the development achieved by children which is given as a foothold to achieve higher development. (Depdiknas, 2016)

The principles of the center approach are: 1) oriented to the needs of children, 2) learning activities carried out through play, 3) stimulating the emergence of creativity and innovation, 4) providing an environment that supports the learning process, 5) developing children's life skills, 6) using various sources and learning media in the surrounding environment, 7) carried out gradually and repeatedly with reference to the principles of child development, 8) educational stimuli that are holistic covering all aspects of development.

One of the centers in Raudhaul Jannah Islamic Kindergarten is the center of science and natural materials. Play centers are zones or play areas for children which are equipped with a set of play devices that serve as the environmental footing needed to support the development of children in 3 types of play, namely: 1) playing sensorimotor or functional, 2) playing a role, and 3) playing development. These three types of play that are always present in every type of children's play activities, including in the centers of science and natural materials. The center of science and natural materials is a place where children play while 
learning to introduce nature and their environment so that children are able to process new information through concrete experiences, explore, classify, stimulate curiosity, find things, explain, elaborate, and evaluate, so that children can learn about the world around them.

\section{METHODS}

This type of research used in this research is qualitative research. Qualitative research in the form of descriptive qualitative research. This type of research aims to describe the situation objectively, the object is developed as is so that research is natural, no manipulation and the presence of researchers has no effect on the object. Data is presented in descriptive form. Qualitative research is research that intends to understand phenomena about what is experienced by research subjects such as behavior, perception, motivation, action, and others. Holistically, and by way of description in the form of words and language, in a special natural context and by utilizing various natural methods (Lexy J. Moleong, 2007: 6)

The design in qualitative research is still temporary and will develop after researchers enter the object of research. Qualitative research assumes reality is holistic, dynamic, and cannot be separated into research variables. Based on the design, in this qualitative study research instruments cannot be developed before the problem under study is clear, therefore in qualitative research the researcher is the main research instrument. However, after the focus of the research is clear, it is possible to develop a simple research instrument, which is expected to complement the data and compare it with data that have been found through observation and interviews and documentation.

The study was conducted at the Islamic Kindergarten Raudhatul Jannah, Payakumbuh City. The reason for choosing Raudhatul Jannah Islamic Kindergarten is because Raudhatul Jannah Islamic Kindergarten is one of the best kindergartens in Payakumbuh, even in West Sumatra. Raudhatul Jannah Islamic Kindergarten has a center for science and natural materials that can be observed in the implementation of science learning for kindergarten-age children.

The sample of this research data source is in the form of words and actions as the main source. While written data sources, photographs and written notes are supporting data sources. The research began with data collection. This data is very important because it is managed properly in order to get true and accurate data. In collecting data researchers use the following data: 1) interview: an interview is an event or an interaction process between the interviewer and the source of information or the person being interviewed through direct communication (Yusuf, 2013: 372). Interviews are conducted in depth and focus on problems so that all the required data can be collected. In order to know the development of children's science at the center of science and natural materials in the Islamic Kindergarten Raudhatul Jannah researchers conducted interviews with related parties namely the principal and teachers, 2) observation: observations on qualitative research that researchers do are unstructured observations, because the focus of the research is unclear. Researchers can make observations freely, record what is seen, do the analysis and then conclusions are made. Observations made by researchers are observations of the implementation of the development process of children's science development at the centers of science and natural materials and teaching activities of teachers while learning takes place, 3 ) documentation: documentation is collected to strengthen the data obtained through interviews and observations. According to Arikunto (2010: 274), documentation techniques are looking for data about things or variables in the form of notes, transcripts, books, newspapers, magazines, inscriptions, minutes of meetings, agendas and so on. In research on the development of children's science at the center of science and natural materials in the Islamic Kindergarten Raudhatul Jannah documents seen relating to learning planning such as semester programs, weekly learning implementation plans (RPPM) and daily learning implementation plans (RPPH). In the implementation of learning documents that are seen and taken in the form of photos of each activity, starting from the opening, core and closing. In evaluating the activities in the form of document evaluation, it is assessed daily, weekly / round, monthly and semester. Other valuation notes are also seen as aknekdot notes.

Data Analysis is the most important step in a research. In this study using the analysis technique of the model of Miles and Huberman (Sugiyono, 2015: 338) can go through four stages of activity steps, namely as follows: 1) data collection: data collection is the most strategic step in research, because the research objectives is getting data. The data obtained can be through interviews, observation and documentation, 2) data reduction: data reduction is a process of selecting, focusing, attention to simplification, abstracting and transformation of data that arises from written records at the research location. Data reduction is done by making summaries, coding, tracing themes, creating clusters, creating partitions and writing memos. This data reduction takes place continuously during qualitative oriented research activities take place, 3) presentation of data (data display): the presentation of data is a collection of structured information that gives the possibility of drawing conclusions and decision making. Presentation of data, researchers can understand what is happening and what must be done based on the understanding of researchers from the presentation of the data, 4) the process of drawing conclusions (conclusion drawing): conclusions are in the form of new findings that had never before existed. The findings can be in the form of a description or description of an object that was previously unclear so that after investigation it becomes clear, it can be a causal or interactive relationship, hypothesis or theory. The process of drawing conclusions starts from searching for the meaning of objects, noting the regularities, patterns, explanations, possible configurations, causal flows and propositions.

\section{RESULT}

Descriptions relating to the results of this study, compiled based on answers to questions in the study through interviews and direct observations in the field, after that are 
equipped with documentation in the form of photos or other documents. Observation starts with looking at learning planning in the center of science and natural materials. The learning implementation plan is a design for teachers to carry out play activities that facilitate children in the learning process created before the learning activities are carried out. The plan must refer to the characteristics (age, social culture and individual needs) of the child.

Signs that must be considered in preparing the learning implementation plan are: 1) understanding the STPPA as the final outcome of the PAUD program (core competencies), 2) understanding basic competencies (KD) as an achievement of learning outcomes, 3) establishing learning material as a content for enriching experience child. After paying attention to these signs, a lesson plan (RPP) is prepared.

The compiler of this RPP aims: 1) to support the achievement of basic competencies and core competencies (IC). 2) support the successful management of meaningful learning. 3) direct the teacher in preparing the tools and materials needed. 4) directing teachers to build attitudes, knowledge and skills that children are expected to have, (Ministry of Education and Culture, 2018).

The results of the interview with the Head of the Islamic Kindergarten Raudhatul Jannah, Mrs. Anidar, S.Pd.AUD, he said:

"Learning planning at Raudhatul Jannah Islamic Kindergarten was designed using the 2013 PAUD Curriculum and local content from the Raudhatul Jannah Islamic Education Foundation. In accordance with the 2013 PAUD Curriculum, learning planning starts from the preparation of the Semester Program. Based on the semester program a weekly RPP (RPPM) is prepared. After that, a daily RPP (RPPH) was prepared. The Semester Program is prepared during the teacher's work meeting at the beginning of the school year. In preparing the semester program the teachers determine the basic competencies to be achieved for each center. This determination aims to ensure that each center focuses on monitoring children's development according to the basic competencies and the indicators for each center selected. After the semester program is finished the center teacher, assisted by the class teacher, starts to prepare the RPPM and RPPH. The preparation of this lesson plan is mandatory for all teachers because this includes the main tasks of the teacher, and also includes points supervised by the principal to be an element of teacher performance appraisal. During this time in Raudhatul Jannah Islamic Kindergarten learning plans are always made by teachers in a complete and well-archived way, including centers of science and natural materials.

Furthermore, researchers looked at the existence of documents ranging from semester programs, RPPM and RPPH. All documents are available, appropriate and well documented. The results of an interview with Mrs. Rama Adrimi, S.Pd as a teacher of the center of science and natural materials said:
"Learning planning starts with seeing the semester program specifically the center of science and natural materials.First seen are the themes and sub themes that will be discussed, after knowing the themes and sub themes then the KD is seen. From the basic competency, the material is determined from each basic competency selected and the main activities that will be given to the child. After that the RPPM began. The material and activities chosen in the RPPM are adjusted to the themes and sub themes discussed at the science and natural materials center. Currently the theme discussed is plants, the sub-theme is corn. After the RPPM is completed, an RPPH is made. The RPPH will be the teacher's guideline in carrying out activities every day starting from the opening, core and closing activities. After the RPPH is completed, equipment is prepared for playing activities at the center. The arrangement of the playing environment is prepared according to the main activities in the RPPH. "

Based on the results of the interview presented by Ms. Anidar, S.Pd.AUD and Mrs. Rama Adrimi, S.Pd that the planning of learning in science and natural materials in the Islamic Kindergarten Raudhatul Jannah has been made and designed in accordance with the main activities that will be carried out every day. Researchers also saw for themselves the existence of a complete and well-documented learning planning document. The arrangement of the playing environment as part of activity planning is also carried out by the teacher the day before the learning activities begin.

Furthermore, researchers want to know how the implementation of learning the development of science at the center of science and natural materials carried out. The implementation of learning is observed by the researcher by observing the footing activities before playing, footing playing and footing after playing. The initial activity after the child enters the center of science and natural materials begins with adjusting the child's sitting position on the carpet facing the blackboard. The teacher starts by reading greetings and absent the child then asks the day and date the child. Then the teacher asks for themes and sub themes. The teacher writes all the children's answers on the board. After that the teacher shows the corn plant and invites children to talk about the corn plant. Only then will the teacher enter into the core learning activities or playing ground.

Before the core activity begins, the teacher mentions the main activities that the child will do, there are five activities, namely: 1) painting guidance from Allah, 2) pounding the corn created by Allah, 3) planting corn created by Allah, 4) floating objects and sinking the creation Allah Most High, 5) playing sand created by Allah Most High. The teacher invites children to the place where the first play activity is to paint leaves.

Children stand in a circle at the activity site. The teacher asks the name of the first activity, the children answer painting leaves. Then the teacher asks the tools used in the activity while pointing to the device, the children mention the name of the device that the teacher points to. The teacher explains how to carry out leaf painting activities 
while giving an example, the children pay attention to what the teacher is doing. The teacher asks if the children understand and can do it according to their own creations, the children answer God willing, ma'am.

The teacher moves to the next activity until the fifth activity. Each activity is explained clearly by the teacher, in order and in detail including the rules in the game activities. After explaining the play activities, the teacher invited the children to choose their friends to play according to the number of each child in the playground. After everything occupies their respective positions, the teacher invites children to play activities.

The children play activities according to the instructions given by the teacher before. Because this research was conducted at the beginning of semester 2, almost all children understood the rules in the game, moreover this activity had been repeated, such as mashing activities, before which pounded was rice on the topic of staple foods, now that was pounded was corn. In playing children also remind each other if there are friends who forget the sequence of activities such as after finishing pounding corn, corn that has been pounded is poured from mortar into a sieve, after pouring all the alunya is placed first in the mortar not placed in any place let alone in the sifted flour container. Here a friend who knows the rules will remind his friend to put the pestle first.

The teacher walks around seeing the children playing activities. The teacher gives questions after the child finishes or while doing play activities such as in pounding the teacher asks the texture of mashed corn that has been sieved compared to that which has not been sieved. Children feel the object directly. The teacher also called corn flour which is also called cornstarch.

In the activity of playing floating and sinking objects the teacher asks the child what is the name of the floating object and what is the name of the submerged object, or the question is if the leaf is placed above the leaf water. In the painting activity, the teacher asks the child to mix colors from the colors of watercolors the child has painted into what colors. In the corn planting activity the teacher asks the child where the corn seeds are planted by the child, how many corn seeds are planted, how can the corn grow properly.

After doing the activities the children tidy up their play equipment by putting it in its original position. After all activities, the teacher invited to wash his hands and sit in a circle again in the carpet. The teacher performs "recolling" activities that have been done by children by asking how children feel during play. The teacher also asks what are the activities that have been carried out by children and the concepts found by children when playing. The child mentions the play activities that he has done and the concepts he has discovered. The teacher says "Thank God", thankful that the children have gained knowledge.

After observing the learning process the researcher also conducted interviews with the school principal, he stated:

"The implementation of science learning at the center of science and natural materials has been going well according to the plans made by the teacher. I always monitor activities in all centers, including centers for science and natural materials.
Schools always facilitate activities that will improve children's abilities including science abilities. This is the mandate of parents of students who have entrusted their children to students in Raudhatul Jannah Islamic Kindergarten. "

The statements made by the principal were understood by the researchers in accordance with what was seen from the learning process in progress. Means that support the implementation of the activity are indeed available and the child can do the activities well.

Furthermore, researchers will observe how the evaluation in the form of learning assessment of science development in science centers and natural materials. From observations that researchers do teachers carry out a direct assessment when the process of playing activities take place. Assessments are carried out routinely every day and are well documented. Daily assessments are then summarized into weekly, monthly and semester assessment summaries. After that the final results of the assessment will be a report to parents at the end of the semester. According to the teacher center about the evaluation in the form of assessment are as follows:

"We carry out assessments every day and are carried out during the learning process. We did this so that we could truly conduct authentic and not fabricated assessments. The results of this daily assessment are summarized into the compilation of assessments, and at the end of the semester we summarize it again in the assessment analysis book and put the final grades into report cards by the class teacher. "

This statement was also reinforced by the principal, from the interview he stated:

"Assessment is an important final set of lessons. The results of the assessment will be useful for teachers to evaluate the activities that have been carried out and will be a material for reflection to be able to plan for the next activity better. The implementation of this assessment also includes the assessment of teacher performance ".

From the results of interviews and direct observation of the assessment documents that researchers see the evaluation process in the form of assessments in science and natural resource centers has been going well and well documented.

\section{DISCUSSION}

Based on research conducted, researchers will describe the discussion of the results of data analysis obtained. Planning is a series of important teaching and learning activities that must be done by the teacher. Planning learning development of science in science centers and natural materials in the Islamic Kindergarten Raudhatul Jannah Payakumbuh City already exists and is in accordance with 
the guidelines in the 2013 PAUD Curriculum and is also adjusted to the vision and mission of the school.

According to the guidelines for the preparation of PAUD learning implementation plans (Kemdikbud, 2018) the steps for preparing the semester program are as follows: 1) establishing basic competencies in each theme. KD determination includes all aspects of the development of Religious and Moral Values (NAM), physical-motor (FM), cognitive (KOG), language (BHS), social-emotional (SOSEM), and art (SN), 2) KD writing can be written complete or just write the code, 3) $\mathrm{KD}$ can be repeated in each theme / sub theme / sub-sub theme is different, 4) make a list of themes for one semester. The selection and determination of themes is done by the teacher before the beginning of the learning activity begins with attention to the principles of theme development, 5) The themes / subthemes / sub-sub-themes that have been determined at the beginning can change if there are certain conditions by involving children without having to change the KD that has been set, 6 ) develop themes into sub-themes and / or subthemes. Subthemes and sub-themes developed are more specific and deeper topics. Specificity and depth of subthemes and sub-themes pay attention to the age of the child, the readiness of the teacher, and the availability of supporting learning resources, 7) determine the time allocation for each theme, sub-theme and or sub-theme. The time for discussion of each theme / sub-theme / sub-theme is adjusted to the child's interests, breadth, depth, and available sources / media.

Based on the steps in preparing the semester program, $\mathrm{KD}$, themes, sub themes, sub-themes and time allocation will be chosen to guide the preparation of RPPM. Each center will create a semester program in accordance with their respective BC. The RPPM is arranged based on the semester program of each center. According to the Guidelines for Preparing an Early Childhood Learning Implementation Plan (Kemdikbud, 2018) the RPPM contains: 1) Identity of service programs, 2) selected KD, 3) learning materials, and 4) planned activities. Program identity includes: (1) Name of PAUD Unit is the name of the PAUD unit that compiles RPPM; (2) Which semester / month / week; (3) Themes / Sub Themes / Sub-Themes are taken from themes / sub themes / sub-themes arranged in the semester program; (4) The age group of children is filled with the program's target group. RPPM in the center of science and natural materials are prepared based on the basic competency selected, based on the specified basic materials and activities given to children during learning.

Daily learning implementation plan (RPPH) is prepared based on the RPPM that has been prepared. According to the Guidelines for the Preparation of an Early Childhood Learning Implementation Plan (Kemdikbud, 2018) the components of the RPPH consist of: 1) program identity, 2) materials, 3) tools and materials, 4) opening activities, 5) core activities, 6) closing activities, and 7) assessment plan. In the preparation of the third component of RPPH namely tools and materials an important concern for teachers because the availability of tools and materials that are suitable to the needs of children's play activities will determine the success and achievement of the learning objectives. The principal as the policy holder plays an important role in developing planning, especially to provide direction, guidance, actions that need to be taken, sources of funds, as well as the facilities needed to achieve maximum learning outcomes.

The implementation of learning to develop science in the center of science and natural materials in the Islamic Kindergarten Raudhatul Jannah Payakumbuh City took place according to the plan that had been prepared by the teacher at RPPH. In the implementation of learning that researchers observe various aspects of child development are developed. The development of children's language can be seen from the child's ability to answer the teacher's questions, the child communicates with his friends when play activities take place and the child is able to mention the activities he has done. The emotional social development of children is also seen when children socialize with their friends when playing, children remind each other, children obey the rules of the game, children can work together and confident. There is a relationship between good science skills and children's language where the child is able to answer questions, tell his playing experiences, and communicate with teachers and friends. Children are happy and excited about their activities.

Evaluation of learning to develop science in the center of science and natural materials in the Islamic Kindergarten Raudhatul Jannah Payakumbuh City in the form of conducting an assessment of the development of science has been done routinely. According to the Guidelines on Evaluation of Learning Outcomes (Kemdikbud, 2018) states the assessment of early childhood education is a process so that it is not only carried out once or twice at a certain time, but continuously and continuously. Assessment does not look good or not the work of children but to analyze the progress of development achieved by children in accordance with the BC and the indicators in the RPPH and other abilities that arise other than those in the RPPH. The results of the assessment will be recommendations for further improvement or improvement of learning.

The assessment begins with a daily assessment conducted during learning. Daily assessment is the most important process in the assessment series. Without daily assessments it is not possible to have weekly, monthly, or even semester assessments that lead to students' development reporting activities to parents. At Radhatul Jannah Islamic Kindergarten, the assessment process has been carried out routinely and is well documented.

\section{CONCLUSION}

Based on research findings and discussion of research results on the learning of science development in the science and natural material centers of the Islamic Kindergarten Raudhatul Jannah Payakumbuh City, it can be concluded that the planning of learning the development of science in the centers of science and natural materials has been carried out accordingly by referring to the 2013 PAUD Curriculum and adjusted to the vision and mission of the school. Planning starts from the semester program, plans for implementing weekly and daily learning. Determination of playing activities in line with the availability of media and props. 
Structuring the main environment is part of the plan which will certainly make the learning process run smoothly.

The process of implementing the learning of science development in the science and natural material center of the Islamic Kindergarten Raudhatul Jannah Payakumbuh City, has been carried out in accordance with the planning in RPPH. Learning takes place according to established procedures, starting from the footing before playing, footing and recolling. Learning also expands other aspects of the development field. A variety of activities along with interesting media and play equipment make children happy and eager to play.

Evaluation of learning in the form of an assessment of science development at the center of science and natural materials in the Islamic Kindergarten Raudhatul Jannah Payakumbuh City is done every day while the learning process takes place. Daily assessments are summarized weekly, monthly and semester. Assessment ultimately leads to the reporting of child development to parents of students. Assessments are carried out routinely and well documented. Assessment is also useful for the improvement and improvement of the quality of subsequent teaching and learning.

In order to improve the quality of learning in the development of science in the center of science and natural materials in the Islamic Kindergarten Raudhatul Jannah, it is recommended that the school principal always pay attention to every planning, implementation and evaluation of learning undertaken by teachers. Conduct curriculum supervision to be more effective in implementing science development learning in Raudhatul Jannah Islamic Kindergarten. Teachers to continue to enhance the creativity of learning, develop types of learning activities that are diverse, interesting and in accordance with the stages of child development.

\section{REFERENCES}

[1] Ajeng Putri Pratiwi, Rika Kurnia, Noviana. 2017.Pengaruh Model Pembelajaran Sentra Bahan Alam Terhadap Kemampuan Sains dan Berbicara Anak Kelompok B di Taman Kanak-kanak. Jurnal Pendidikan Usia Dini. 11 (1): 67 - 82

[2] A Muri Yusuf. 2005. Metodologi Penelitian (Dasardasar Penyelidikan Ilmiah ). Padang UNP Press

[3] Dadan Suryana. (2014). Dasar-dasar Pendidikan TK. Jakarta. Universitas Terbuka. Hal. 1 - 65

[4] Dadan Suryana. (2014). Kurikulum Pendidikan Anak Usia Dini Berbabasis Perkembangan Anak. Jurnal Pesona Dasar.Vol. 1 No. 3, hlm 65 - 72

[5] Dadan Suryana. (2017). Pembelajaran Tematik Terpadu Berbasis Pendekatan Saintifik Di Taman Kanak-Kanak.Jurnal Pendidikan Usia Dini Volume 11 Edisi 1, hlm 67 - 82
[6] Dadan Suryana. (2018). Stimulasi dan Aspek Perkembangan Anak. Jakarta. Kencana

[7] Depdiknas, Dirjend PLS, Direktorat PAUD. (2006). Pedoman Penerapan Pendekatan Beyond Centers and Circles Time (BCCT) (Pendekatan Sentra dan Saat Lingkaran) dalam Pendidikan Anak Usia Dini. Jakarta

[8] Diana, Anandita Eka Setiadi. 2018. Bahan Ajar Sains Anak Usia Dini Berbasis Kearifan Lokal dan Nilai Keislaman. Jurnal Pendidikan Usia Dini. 12 (2) : $212-220$

[9] Hurlock, Elizabeth. (1978). Perkembangan Anak Edisi ke Enam. Jakarta: Erlangga.

[10] Hartati, SOFIA. (2005). Perkembanagan Anak Usia Dini.Jakarta: Departemen Pendidikan Nasional

[11] Khadijah. 2015. Pengembangan Kognitif Anak Usia Dini. Medan. Perdana Publishing

[12] Kemendikbud, Dirjend PAUD Dikmas, Direktorat Pembinaan PAUD. (2018). Pedoman Penilaian Hasil Pembelajaran. Jakarta

[13] Kemendikbud, Dirjend PAUD Dikmas, Direktorat Pembinaan PAUD. (2018). Pedoman Penyusunan Rencana Pelaksanaan Pembelajaran Pendidikan Anak Usia Dini. Jakarta

[14] Kemendikbud, Dirjend PAUD Dikmas, Direktorat Pembinaan PAUD. (2018). Pedoman Pengelolaan Kelas Pendidikan Anak Usia Dini. Jakarta

[15] Kemendikbud, Dirjend PAUD Dikmas, Direktorat Pembinaan PAUD. (2018). Pedoman Pengelolaan Pembelajaran Pendidikan Anak Usia Dini. Jakarta

[16] Martini Jamaris. (2003). Perkembangan dan Pengembangan Anak Usia Taman Kanak-kanak, Jakarta: Grasindo.

[17] Mela Murti Roza. 2012. Pelaksanaan Pembelajaran Sains Anak Taman Kanak-kanak Aisyiyah Bustanul Athfal 29 Padang. Jurnal Pesona PAUD. 1 (1): 1 11

[18] Nurul Hidayah Br Dalimunte. 2017. Implementasi Pembelajaran Keterampilan Sains Di Tk Al-Faruq Tanjung Morawa T.A 2017/2018. Skripsi. Universitas Islam Negeri Sumatera Utara Medan

[19] Sugiyono. (2015). Memahami Penelitian Kualitatif. Bandung: CV. Alfabeta 
[20] Suyanto, Slamet 2005. Konsep Dasar Pendidikan Anak Usia Dini. Jakarta: Depdiknas

[21] Tedjasaputra, Mayke S. 2001. Bermain dan Permainan. Jakarta: Grasindo.
[22] A Muri Yusuf. 2005. Metodologi Penelitian (Dasardasar Penyelidikan Ilmiah ). Padang: UNP Press 